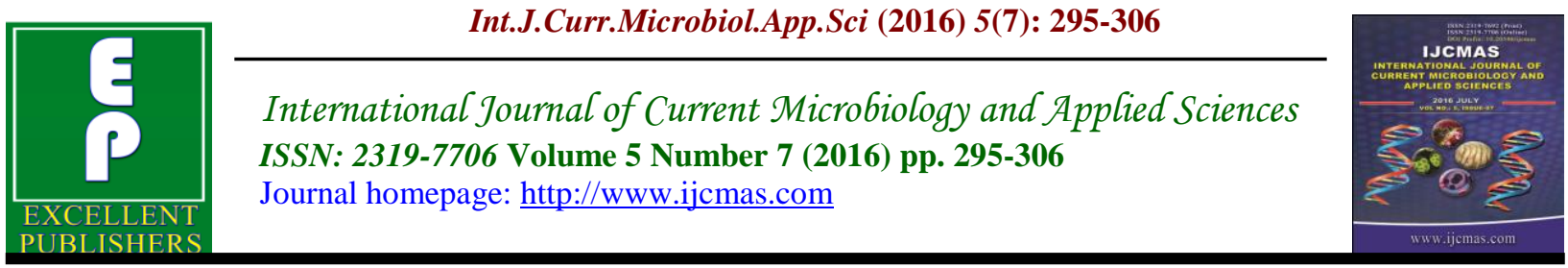

Original Research Article

http://dx.doi.org/10.20546/ijcmas.2016.507.031

\title{
L-Asparaginase from Marine Actinomycetes of Thoothukudi Coastal Ecosystem
}

\author{
P. Dhevagi ${ }^{1}$ * and E. Poorani ${ }^{2}$ \\ ${ }^{1}$ Department of Environmental Sciences, Tamil Nadu Agricultural University, \\ Coimbatore-641 003, Tamil Nadu, India \\ ${ }^{2}$ Department of Biotechnology, Government College of Technology, \\ Coimbatore-641 003, Tamil Nadu, India \\ *Corresponding author
}

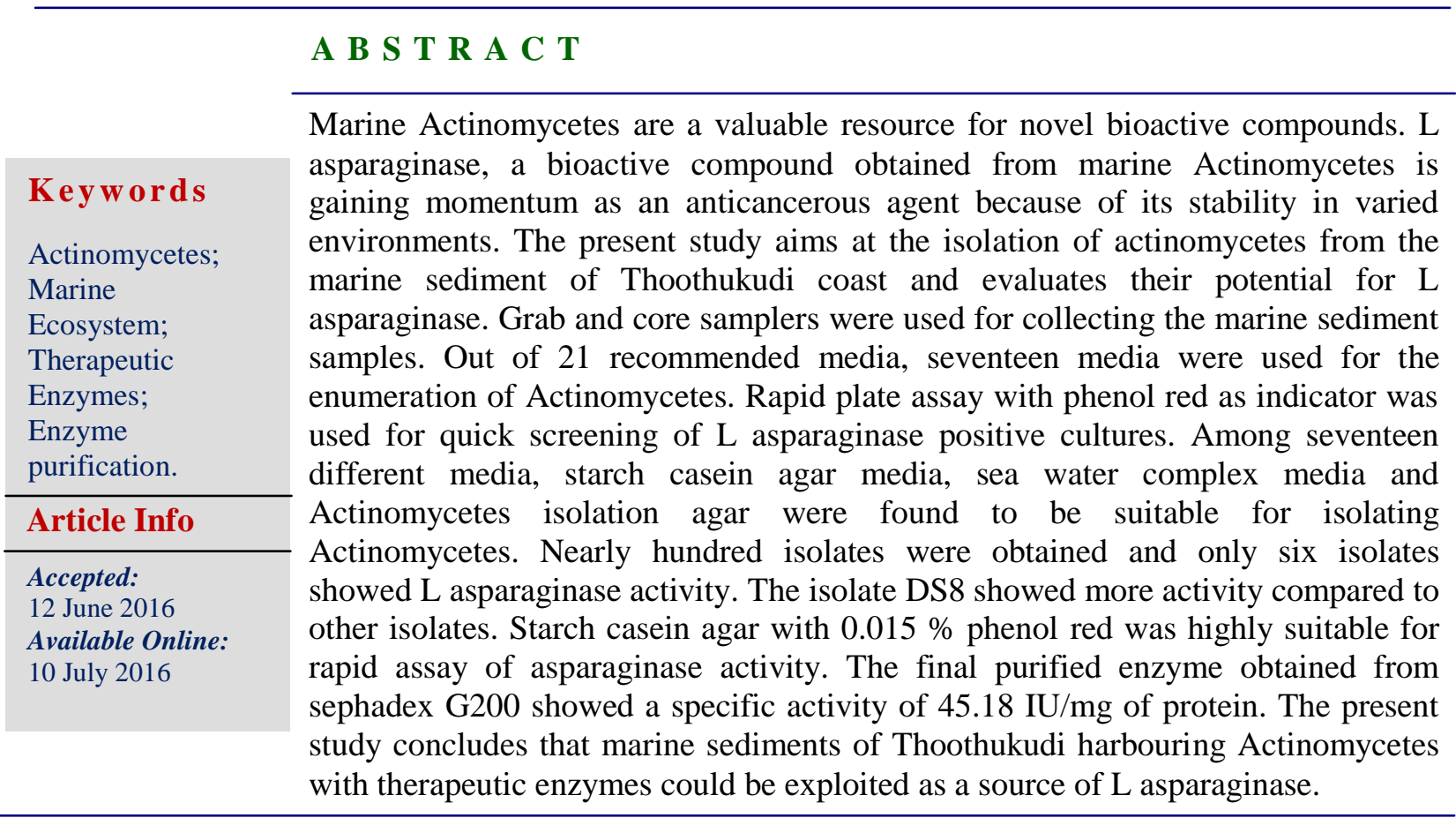

\section{Introduction}

During recent years, the rate of discovery of new compounds from terrestrial Actinomycetes has decreased and it is crucial that new groups of Actinomycetes from under exploited habitats be explored as sources of novel bioactive secondary metabolites. Marine actinomycetes are the most economically and biotechnologically valuable prokaryotes and are best known for their ability to produce bioactive compounds which are relatively more stable and active than the corresponding enzymes from plants and animals (Lam, 2006, Bull et al., 2000). They provide a good source of new secondary metabolites due to the fact that they are adapted to a marine habitat. Like bacteria, actinomycetes are also a good source of L- asparaginase (Savithri and 
Azmi, 2003). Marine bacteria producing L asparaginase enzyme were isolated by many workers (Meena et al., 2015; Bhargavi and Jayamadhuri, 2016; Dhevagi and Poorani, 2006). Not only the qualitative study, quantitative study was also being done many workers (Selvam and Vishnupriya, 2013.). In one of their study Streptomyces acrimycini with a total activity of $1510 \mathrm{U} / \mathrm{ml}$ with a specific activity of $10.79 \mathrm{U} / \mathrm{mg}$ of protein was reported.

Isolation and characterization study of Actinomycetes reveal that the marine Actinomycetes from coastal environment are the potent source of novel antibiotics and can be useful in the discovery of novel species (Valli et al., 2012). Thus, there is enormous scope for investigations that explore the probabilities of deriving new products from potential marine actinomycetes. Although some work has been done on marine actinomycetes not much work has been done with the microflora of coastal areas of Thoothukudi, which is a unique habitat and hence there is a potential for isolates with novel therapeutic activity. Hence, the present investigation was designed for the isolation of marine actinomycetes suitable for therapeutic applications from the coastal zone of Thoothukudi in Tamil Nadu

\section{Materials and Methods}

\section{Sample Collection}

Marine sediment samples were collected from six different locations viz., Threspuram (TS), Meenavar Kuppam (MK), Beach road near Roach Park (RP), Harbor camp (HC), Deep sea sediments (D1, D2) from Thoothukudi district of Tamil Nadu. Depending upon the location either Grab sampler or Core sampler was used for collecting the samples. Alcohol rinsed
Peterson Grab sampler (RISC, 1999) was used for collecting deep sea sediments samples (D1 and D2) and core sampling method was used in the case of TS and MK. The samples RP and HC were collected from the rhizosphere region of mangrove plants (Günter et al., 2009). The depth of sample collection varied from 1 feet to 20 feet. Subsamples of minimum three was taken and mixed as composite samples.

The sediments were transferred to sterile polyethylene bags before transported to the laboratory and were analyzed for its physical, chemical (APHA, 1989) and biological properties (Cappuccino and Sherman, 2004).

\section{Enrichment}

Pretreatments are essential before enumerating Actinomycetes from marine sediments. In the present investigation two methods of pretreatments were followed as a preliminary step. In the first method, one gram of sediment was transferred to a conical flask containing $100 \mathrm{ml}$ of sterile starch casein broth and incubated at $37^{\circ} \mathrm{C}$ for 14 days in an incubator cum shaker. In the second method the sediment samples were dried and heated at $80^{\circ} \mathrm{C}$ for 2 hours and then inoculated into starch casein broth and incubated.

Several different combinations of media have been suggested for the isolation of Actinomycetes from soil (Waksman, 1961). Out of 21 recommended media, seventeen media (Kuster and Williams, 1964; Paul et al., 1991; Shirling and Gottlieb, 1966; Selvakumar, 2011 and Poorani et al., 2009) were selected to determine the efficacy for isolation, growth and activity of Actinomycetes from the marine sediment samples. After incubation, growth of the Actinomycetes was observed in all the 
seventeen media and evaluated for their suitability to enumerate the Actinomycetes from enriched marine sediments.

\section{Screening for $\mathrm{L}$ asparaginase}

Screening for L-asparaginase activity was done with rapid plate assay method (Imada 2005). This method was found to be more advantageous as this method is quick and results can be visualized directly from the plates. Screening for enzyme activity was done with starch casein agar media spiked with different concentrations of the phenol red dye. A $2.5 \%$ dye was prepared in ethanol and the $\mathrm{pH}$ was adjusted to 7.0 using $1 \mathrm{~m}$ $\mathrm{NaOH}$ and added to the SCA medium. Then the medium was plated along with the control and inoculated with $72 \mathrm{hr}$ old isolates for rapid screening of the enzyme activity.

The diameter of the colonies and the diameter of total clear hydrolytic halos including the colonies were determined. The strains that yielded higher halos were selected as potential strains for Lasparaginase production using asparagine as substrate. Percent of the cleared zone was calculated as per the formula given below.

Percent of cleared zone $=$

Diameter of the cleared zone - Diameter of the colony $\times 100$

Diameter of colony

The isolate which showed asparaginase activity were further characterized (Shirling and Gottlieb 1966) before purifying the enzyme.

\section{Partial Purification of $L$ asparaginase}

Sterilized starch casein broth $(\mathrm{pH} 7.0)$ was inoculated with promising isolates obtained from the plate assay and incubated at $30^{\circ} \mathrm{C}$ for 3 days in an incubator cum shaker. After incubation, the enzyme was extracted by centrifugation and assayed for Lasparaginase activity. For further purification, the crude enzyme was brought to 45 per cent saturation with ammonium sulfate at $\mathrm{pH}$ of 8.4 and kept overnight in a cold room for calibration. Then the supernatant was centrifuged at $4200 \mathrm{rpm}$, for $10 \mathrm{~min}$ at $4^{\circ} \mathrm{C}$. The same process was repeated and the supernatant was brought to 85 per cent saturation with ammonium sulfate. The precipitates were collected and dissolved in $1 \mathrm{M}$ Tris $\mathrm{HCl}$ buffer and dialyzed using pretreated dialysis tubes. Dialyzed precipitates were dissolved in 0.05 $\mathrm{M}$ Tris $\mathrm{HCl}(\mathrm{pH}$ 8.4) buffer and was loaded onto pre-equilibrated Sephadex G 50 column using $0.05 \mathrm{M}$ Tris $\mathrm{HCl}(\mathrm{pH}$ 8.4) containing $0.1 \mathrm{M} \mathrm{KCl}$ elution buffer. The same process was repeated with Sephadex G 200 column. Fractions were collected at a flow rate of $5 \mathrm{ml} / 30$ min from both the columns and assayed for L-asparaginase activity (Narayana et al., 2007, Amena et al., 2010). All the process was carried out at $4^{\circ} \mathrm{C}$

\section{Results and Discussion}

Marine sediment samples collected from Thoothukudi coastal zone were analyzed for physical - chemical and biological properties. Sediment samples collected from Threspuram (TS) were clay with fine organic materials and MK, D1 and D2 sediments were found to be muddy sand types. All the samples showed had an alkaline $\mathrm{pH}$ ranging from 8.41 to 8.52 and drastic variation was observed in case of EC (1.96 to $9.36 \mathrm{dSm}^{-1}$ ). The organic carbon content of the samples varied from 5.1 to $13.3 \%$. The collected sample had very low bacterial and fungal population. The bacterial population varied from 30 to $170 \mathrm{x}$ $10^{2}$ per gram of sediment sample and fungal 
population varied from 20 to $110 \times 10^{1}$ per gram of sediment. The population of Actinomecetes varied from 6 to $32 \times 10^{1} / \mathrm{g}$ of sediment sample. Sample from Meenavar Kuppam and Roach Park recorded highest actinomecetes population $24 \times 10^{1}$ and $32 \mathrm{x}$ $10 \%$ g of sediment respectively. Thoothukudi sediment samples were enriched by 14 days and incubated in SC broth as mentioned earlier. After enrichment, the cultures were isolated in media supplemented with cycloheximide $50 \mu \mathrm{g} / \mathrm{ml}$ and nalidixic acid $35 \mu \mathrm{g} / \mathrm{ml}$.

\section{Screening different media}

After thorough scanning of literatures, seventeen different specific media were screened for the isolation of actinomycetes from enriched marine sediment samples (Table 1). Among the different media used for screening of actinomycetes, starch casein agar media, sea water complex media, actinomycetes isolation agar showed the highest number of colonies as compared to other media (fig. 1). Least population was observed in modified M9 media and Kenknight agar.

As far as colony growth pattern was concerned good growth was observed with different types of morphologies in few media. In Seawater Complex agar medium, large sized, white cottony growth was observed. In Actinomycetes Isolation agar medium, small sized, white colored colonies were observed. Large size, white colored colonies with fiber like growth surrounding the colonies were observed in the starch casein agar medium.

The number of isolates from sampling locations TS, MK, RP, HC, D1 and D2 were $12,13,28,15$ and 16 respectively. A total of 108 individual colonies with different macroscopic characteristics, colony size and texture were selected and all these isolates were subjected to rapid plate assay method for testing the $\mathrm{L}$ asparaginase activity. Among the isolates which had enzyme activity in rapid plate assay were used for further study. Among six positive isolates and DS 8 isolated from deep sea using a grab sampler was subjected to purification of $\mathrm{L}$ asparaginase.

\section{Screening for L-asparaginase activity}

The cultures showing positive results for $\mathrm{L}$ asparaginse were screened for different phenol red concentration (0.001 to $0.019 \%$ ) to fix the minimum dye concentration for effective and quick isolation. The isolates TS 3, DS7 and DS 8 produced larger zone and among the three isolates DS 8 showed highest zone $(20.7 \mathrm{~mm})$ and significantly different from other isolates. Hence this isolate was characterized and used for enzyme extraction and purification study.

The characteristic of the promising isolate DS8 was presented in table 2 and 3. The isolate showed grey colored growth without any motility. The staining reaction of the isolate was gram positive and acid fast negative. It has hydrolyzed casein and starch, but not utilized cellulose. In addition, it preferred glucose as carbon source, but also grow in mannital and fructose containing media. Sucrose was not utilized and differences were observed in the case of nitrogen utilization. DS 8 strongly utilizes L asparagine and L Phenylalanine was not utilized.

\section{Partial purification of l-asparaginase}

The crude enzyme extract was assayed for $\mathrm{L}$ asparaginase activity after estimating the protein content. Results obtained in the purification of $\mathrm{L}$ asparaginase were given in Tabl4. The crude enzyme extract had a total 
activity of $368.3 \mathrm{U} / \mathrm{ml}$ with specific activity of $0.86 \mathrm{u} / \mathrm{mg}$. The crude enzyme extract when subjected to purification using ammonium sulfate precipitation, the total activity was $242.8 \mathrm{U} / \mathrm{ml}$ with a specific activity of $0.88 \mathrm{U} / \mathrm{mg}$. When the precipitate passed through sephadex G 50 column, the specific activity was increased $(20.08 \mathrm{U} / \mathrm{mg})$ and it was around $45.18 \mathrm{U} / \mathrm{mg}$ when the precipitate was passed through sephdex $G$ 200 column. One IU is $1 \mathrm{mM}$ of ammonia per minute per $\mathrm{ml}$ at $37^{\circ} \mathrm{C}(1 \mu \mathrm{m} /$ minute $/ \mathrm{ml})$

\section{Enrichment of sediment samples}

Marine sediment samples collected from Thoothukudi coastal zone were analyzed for physical - chemical and biological properties. The entire sample recorded very low actinomycetes population (6 to $32 \mathrm{x}$ $10^{1} / \mathrm{gram}$ of sediment) and this observation necessiated to carry out enrichment before enumerating the actinomycetes population.

Many studies had indicated that enrichment of samples in selective media led to the isolation of new actinomycetes strains from marine sediment samples. In addition, for selective development of actinomycete colonies, mixture of antibiotics was tested for its selective efficiency (Porterj et al., 1960).

Heat treatment method is also often used for the pre treatment of marine sediments, prior to actinomycete isolation, to reduce the numbers of gram-negative bacteria commonly found in marine samples. Nalidixic acid was used in Starch casein medium to enhance actinomycetes counts of marine sediments (Takizawa, 1993). The effectiveness of addition of NA to the isolation medium on actinomycete counts was compared with conventional heat pre treatment. In general, counts obtained from an isolation medium supplemented with NA were similar, both with and without heat pre treatment, but were significantly higher than counts from preheat treatment alone.

The present study reveals that incubating the sample for 14 days at $37^{\circ} \mathrm{C}$ followed by plating on media supplemented with cycloheximide $50 \mu \mathrm{g} / \mathrm{ml}$ and nalidixic acid $35 \mu \mathrm{g} / \mathrm{ml}$ was found to be good for isolating Actinomycetes cultures from marine sediments. This was in line with the findings of many researchers (Imada 1973).

\section{Screening different media}

Glucose asparagine agar, Green and Meyer's agar and Kusters Agar were found to be the suitable media for isolation of actinomycetes from air dried sediment samples (Kuster and Williams, 1964). Nystatin was used in Kuster's agar for isolation of actinomycetes from mangrove sediments (Meena et al., 2015). Cyclohexamide and nalidixic acid was used in the ISP2 medium for the isolation of actinomycetes from sea surface macro layer (Hakvag et al., 2008).

In the present study 17 different media were used for screening. The number of days of incubation also played a major role in the development of the colonies. As the duration of incubation increases the numbers of colonies were also increased to some extent. In few media significant increase was observed and in many media the result was not at a significant level. Based on the above study it was inferred that Sea Water Complex agar, starch casein agar and Actinomycetes isolation agar were highly suitable for isolating marine Actinomycetes. Hence, these media were used for the isolation of actinomycetes from the sediments supplemented with cyclohexamide $50 \mu \mathrm{g} / \mathrm{ml}$ and nalidixic acid $30 \mu \mathrm{g} / \mathrm{ml}$. Isolates obtained from the selected media were purified and maintained. 
Table.1 Screening of different media for enumeration of marine actinomycetes

\begin{tabular}{|c|c|c|c|}
\hline S.No & Media used & $\begin{array}{l}\text { Growth } \\
\text { pattern }\end{array}$ & Morphology \\
\hline 1 & Kenknight agar (14) & Moderate & White colonies \\
\hline 2 & $\begin{array}{l}\text { Sea water complex agar (SWC ) } \\
\text { (15) }\end{array}$ & Very Good & $\begin{array}{l}\text { Larger, well defined and white } \\
\text { colored colonies }\end{array}$ \\
\hline 3 & $\begin{array}{l}\text { Actinomycetes isolation agar } \\
\text { (AIA) (16) }\end{array}$ & Very Good & $\begin{array}{l}\text { White well defined small } \\
\text { colonies with cottony growth. }\end{array}$ \\
\hline 4 & Modified M9 media (MM9) (17) & Moderate & Bright White colonies \\
\hline 5 & Nutrient agar (NA) (12) & Poor & White colonies \\
\hline 6 & $\begin{array}{lll}\begin{array}{l}\text { Modified } \\
(\text { MMA)(16) }\end{array} & \text { Nutrient } & \text { Agar }\end{array}$ & Moderate & $\begin{array}{l}\text { Few colonies with creamy } \\
\text { centre }\end{array}$ \\
\hline 7 & $\begin{array}{l}\text { Starch casein agar ( SCA) } \\
\text { (16) }\end{array}$ & Very Good & $\begin{array}{l}\text { Well defined larger dirty } \\
\text { white, fibrous margins. }\end{array}$ \\
\hline 8 & $\begin{array}{l}\begin{array}{l}\text { Starch Nitrate Agar } \\
\text { (SNA) (12) }\end{array} \\
\end{array}$ & Moderate & Grey, powdery colonies \\
\hline 9 & $\begin{array}{l}\text { Tryptone Yeast Extract Broth ( } \\
\text { ISP 1) (16) }\end{array}$ & Moderate & tion \\
\hline 10 & $\begin{array}{l}\text { Yeast Extract } \text { Malt } \quad \text { Extract } \\
\text { Medium } \\
\text { ( ISP 2) (16) }\end{array}$ & G & es \\
\hline 11 & $\begin{array}{l}\text { Oat Meal Agar Medium ( ISP 3) } \\
\text { (16) }\end{array}$ & Moderate & Dull white thick colonies \\
\hline 12 & $\begin{array}{l}\text { Inorganic Salt } \quad \text { Starch } \\
\text { Medium Agar } \\
(\text { ISP-4) (16) }\end{array}$ & $\mathrm{d}$ & olonies \\
\hline 13 & $\begin{array}{l}\text { Glycerol-Asparagine } \\
\text { medium } \\
\text { ( ISP 5) (16) }\end{array}$ & Good & Dark colored colonies \\
\hline 14 & $\begin{array}{l}\text { Peptone Yeast Extract agar } \\
\text { medium (ISP-6) (16) }\end{array}$ & Poor & Thin colonies with pigment \\
\hline 15 & $\begin{array}{l}\text { Tyrosine Agar Medium( ISP -7) } \\
\text { (16) }\end{array}$ & Good & Thick grey colored colonies \\
\hline 16 & $\begin{array}{l}\text { Potato Dextrose Agar medium } \\
\text { (12) }\end{array}$ & Good & $\begin{array}{l}\text { Convex surface with mycelial } \\
\text { growth }\end{array}$ \\
\hline 17 & $\begin{array}{l}\text { Carbon Utilisation Agar (ISP 9) } \\
\text { (16) }\end{array}$ & Moderate & $\begin{array}{l}\text { Yellowish surface with little } \\
\text { mycelial growth }\end{array}$ \\
\hline
\end{tabular}


Table.2 Morphological and Biochemical characteristics of the Promising Isolate DS8

\begin{tabular}{|l|l|}
\hline \multicolumn{1}{|c|}{ Characteristics } & Results \\
\hline Colony color & Grey \\
\hline Gram staining & + \\
\hline Acid fast & - \\
\hline NaCl requirement 5\% (w/v) & + \\
\hline Optimum temperature & \multicolumn{2}{|c|}{$37-40^{\circ} \mathrm{C}$} \\
\hline Optimum pH range & $7-8$ \\
\hline Catalase activity & - \\
\hline Oxidase & - \\
\hline Nitrate reduction & + \\
\hline Methyl red & + \\
\hline Voges Proskeur & - \\
\hline Gelatin utilization & + \\
\hline Starch degradation & + \\
\hline Casein hydrolysis & + \\
\hline
\end{tabular}

Table.3 Nutritional Characteristics of the Promising Isolate DS8

\begin{tabular}{|l|l|}
\hline Characteristics & Results \\
\hline Cellulose degradation & - \\
\hline Glucose & ++ \\
\hline Arbinose & + \\
\hline Sucrose & - \\
\hline Mannitol & + \\
\hline Inositol & + \\
\hline Xylose & + \\
\hline Fructose & + \\
\hline Rhamnose & + \\
\hline L-asparagine & ++ \\
\hline Leucine & ++ \\
\hline Tyrosine & ++ \\
\hline L-phenylalanine & - \\
\hline
\end{tabular}

$(+)$-- Indicates positive, $\quad(-)$-- Indicates negative, $\quad(++)$-- Indicates strongly positive

Table.4 Purification of L-asparaginase enzyme from promising Isolate DS8 actinomycetes

\begin{tabular}{|l|c|c|c|}
\hline \multicolumn{1}{|c|}{ Purification Steps } & $\begin{array}{c}\text { Total protein } \\
(\mathrm{mg})\end{array}$ & $\begin{array}{c}\text { Total Activity } \\
(\mathrm{IU})\end{array}$ & Specific Activity ( IU) \\
\hline Crude extract & 429.5 & 368.3 & 0.86 \\
\hline $\begin{array}{l}\text { Ammonium Sulphate } \\
\text { precipitation 45-85\% }\end{array}$ & 274.2 & 242.8 & 0.88 \\
\hline Sephadex G 50 filtration & 1.06 & 21.29 & 20.08 \\
\hline Sephadex G 200 filtration & 0.16 & 7.20 & 45.18 \\
\hline
\end{tabular}

IU: Amount of enzyme which catalyses the formation of $1 \mu \mathrm{mol}$ of ammonia per min under the conditions of the assay 
Fig.1 Screening different media for Actinomycetes isolation

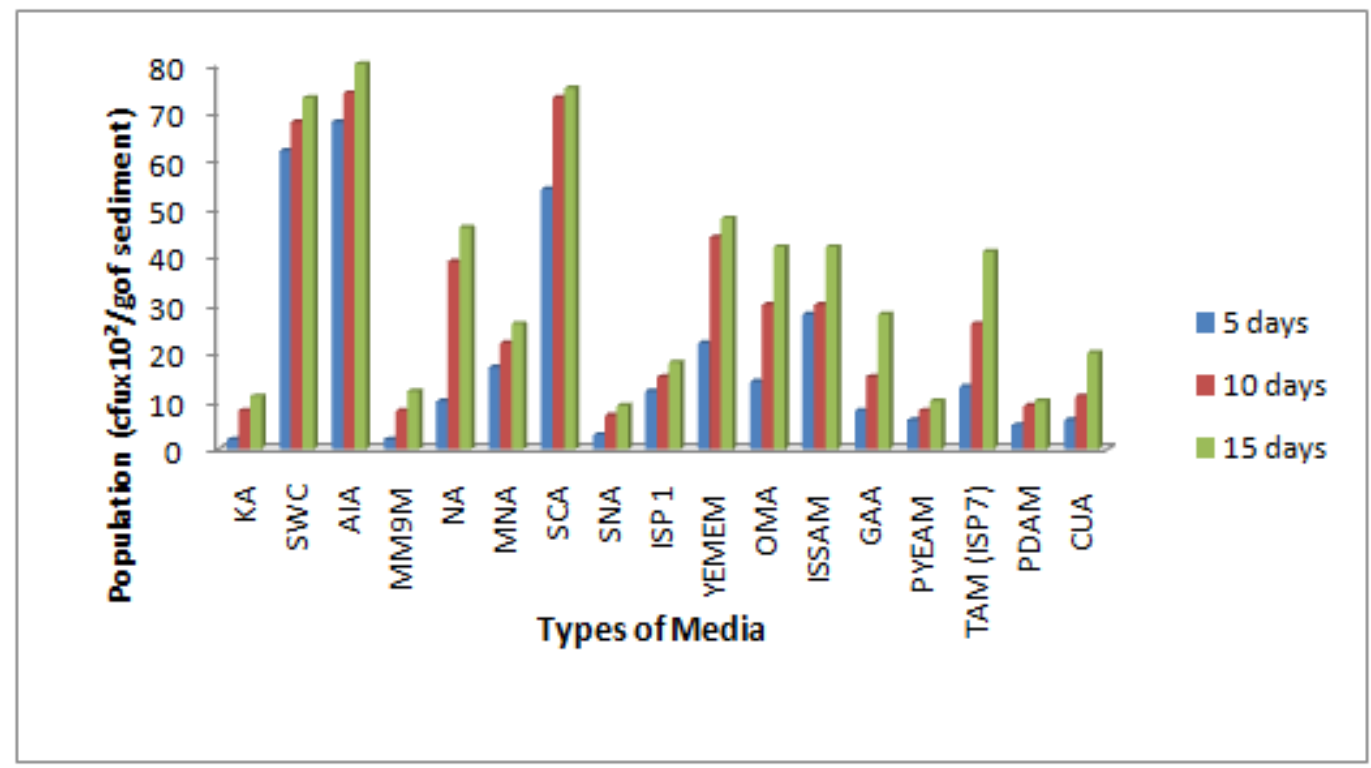

Fig.2 Standardization of Phenol red concentration

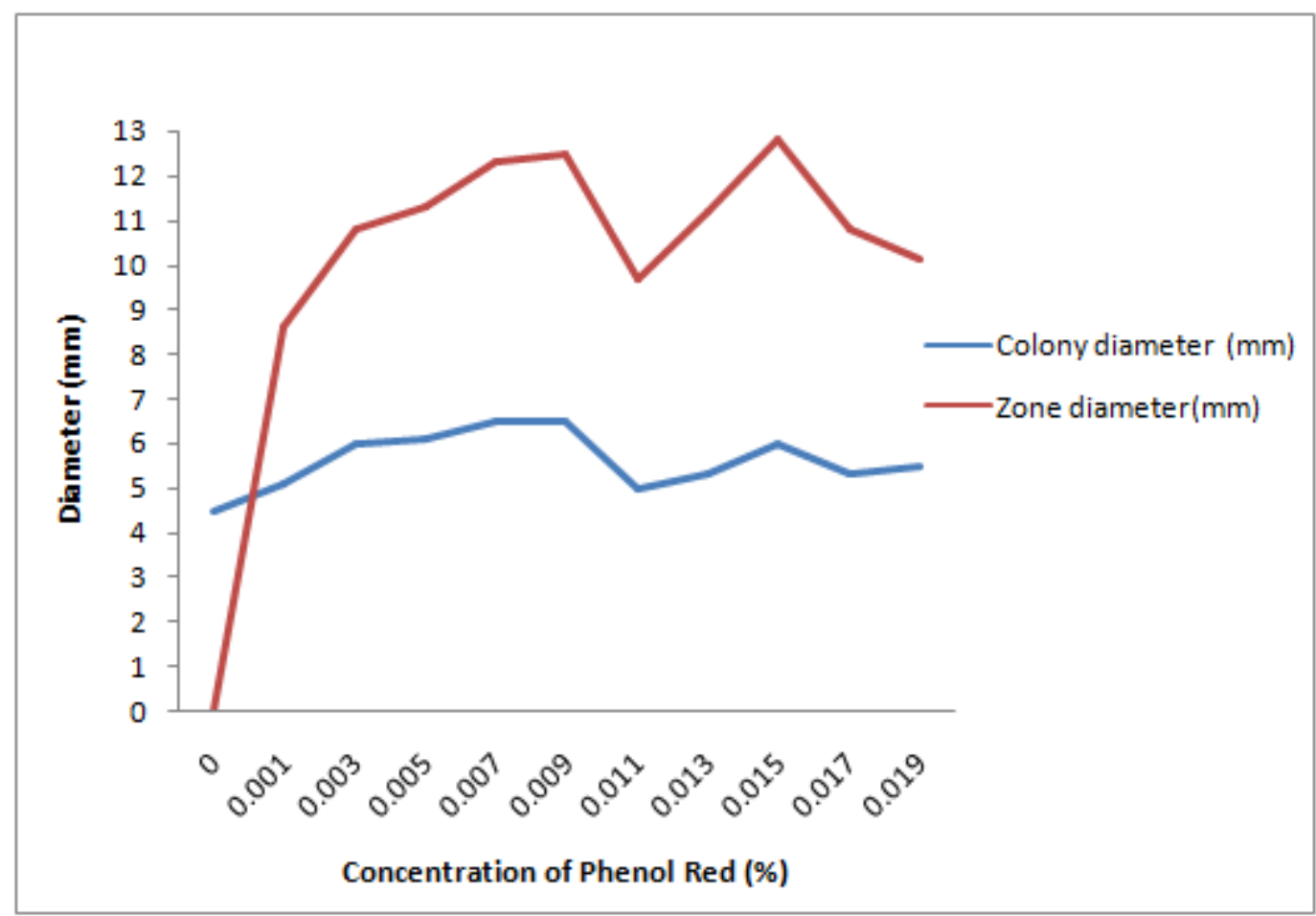


Fig.3 Zone of Clearance in Starch Casein Agar with phenol red

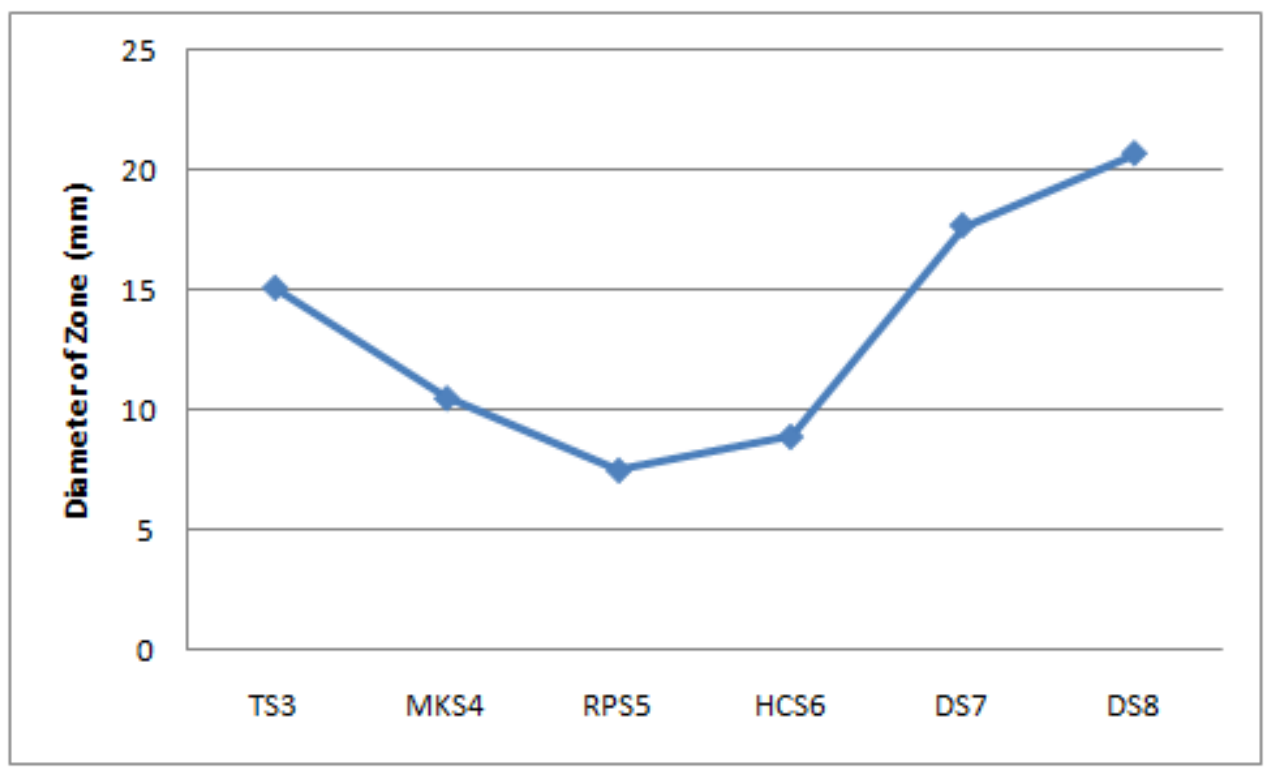

\section{Screening for L-asparaginase activity}

The plate assay used for screening asparaginase activity was found to be more advantageous as this method is quick and results can be visualized directly from the plates. The plates were inoculated with $72 \mathrm{hr}$ old culture of the isolates and the isolates which showed the zone of pink coloration indicated the production of $\mathrm{L}$ asparaginase. The change in color of the media may be due to the liberated ammonia from L asparainase accompanied by an increase in $\mathrm{pH}$ of the culture filtrates. This study with different concentration of the dye reveals that as the concentration of the dye increases the visibility of the zone also increases and the dye didn't inhibit the growth of the test organisms. Since the zone of clearance was high at $0.015 \%$ phenol red, the starch casein agar was supplemented with $0.015 \%$ phenol red was used for plating (fig 2). This was higher than the concentration used by the earlier workers (Valli et al., 2012; Gulati et al., 1997)

After standardizing the phenol red concentration for rapid plate assay, all the six isolates was tested for the enzyme activity (fig 3). As reported by earlier workers (De Jong, 1972), the plate assay indicates the positive cultures without consuming much time for screening. The positive isolates were characterized (Table 3 ) and it was identified by growth on agar surface, physiological and enzymatic properties, carbon utilization and nitrogen utilization as Streptomyces sp, but needs molecular confirmation.

\section{Partial purification of $L$ asparaginase}

The isolate DS 8 obtained from Thoothukudi was used for purification of enzymes from crude extract. After $45 \%$ saturation with ammonium sulfate, the pellet was used for the estimation of protein and for $\mathrm{L}$ asparaginase enzyme assay. It was observed that the $45 \%$ ammonium sulfate purified sample showed a specific activity of 0.88 $\mathrm{IU} / \mathrm{mg}$, and in the final purification step the enzyme showed a specific activity of 45.18 IU / mg of protein. The culture filtrate of atinomycetes isolated from the marine sediments with L-asparaginase activity was reported earlier by many workers (Distasio 
et al., 1976; Manna et al., 1995; Sivakumar et al., 2006) and the present study also confirms that. Thus there is enough scope for new source of L-asparaginase with better therapeutic properties, which may help to prevent or reduce the side effects reported earlier. Hence, the focus on L-asparaginase from marine actinomycets may lead to exploration of new source for novel anticancer enzyme.

In conclusion, studies have shown that marine actinobacteria were found to be a good source for therapeutic L-asparaginase. However these studies have been completed only upon the isolation of marine actinobacteria from marine environment for screening of L-asparaginase potentials. Thus further substantial research is needed to explore the potential of marine actinomycetes. Despite some of the potential hindrances to the extraction of enzymes from actinomycetes, the current awareness regarding the compounds from biological origin indicates that marine actinomycete application to therapeutic industry deserves attention.

\section{Acknowledgements}

The authors are thankful to the University Grants Commission, Government of India for their financial support. Also thankful to the Fisheries College and Research Institute, Thoothukudi for helping in collecting marine sediments.

\section{References}

Amena, S., Vishalakshi, N., Prabhakar, M., Dayanand, A., Lingappa, K. 2010. Production, purification and characterization of 1-asparaginase from Streptomyces gulbargensis Braz J. Microbiol., 41(1): 173-178.
APHA. 1989. Standard methods for estimation of water and wastewater, 16th Edn.American Public Health Association, Washington DC

Bhargavi, M., Jayamadhuri, R. 2016. Isolation and screening of marine bacteria Producing Anti Cancer Enzyme Lasparaginase. American J. Marine Sci., 4: 1-3.

Bull, A.T., Ward, A.C., Goodfellow, M. 2000. Search and discovery strategies for biotechnology: The paradigm shift. Microbiol. Mol. Bio. Rev., 64 : 573606.

Cappuccino, J.G., Sherman, N. 2004. Microbiology: A laboratory manual, 6 th addition, Pearson education (Singapore) Pvt. Ltd, Indian branch, 482 FIE Patparganj, New Delhi,: 143185.

De Jong, P. 1972. L - Asparaginase production by Streptomyces griseus. Appl. Microbiol., 23: 1163-1164.

Dhevagi, P., Poorani, E. 2006. Isolation and characterization of L-asparaginase from marine actinomycetes. Ind.J. Biotechnol., 5: 514-520.

Distasio, J.A., Niderman, R.A., Kafkewitz, D. 1976. Purification and Characterization of $\mathrm{L}$ asparaginase with Anti-Lymphoma activity from Vibrio succinogens. Jr. Biol. Chem., 251(22): 6929-6933.

Gulati, R., Saxena, R.K., Gupta, R. 1997. A rapid screening for L-asparaginase producing microorganisms. Letters in Appl. Microbiol., 24: 23-26.

Günter, N., George, T.S., Plassard, C. 2009. Strategies and methods for studying the rhizosphere-the plant science toolbox. Plant Soil, 321: 431-456.

Hakvag, S., Fjarvik, E., Josefsen, K.D. 2008. Characterization of Streptomyces spp. Isolated from the sea surface microlayer in the Trondheim Fjord, Norway. Mar. Drugs, 6: 620-635. 
Imada, A., Igarasi, S., Nakahama, K., Isono M. 1973. Asparaginase and glutaminase activities of microorganisms. J. Gen. Microbiol., 76: $85-89$.

Imada, C. 2005. Enzyme inhibitors and other bioactive compounds from marine actinomycetes. Antonie Van Leeuwenhoek; 87: 59-63.

Kuster, E., Williams, S.T. 1964. Selective media for the isolation of Streptomycetes. Nature, 202: 928 929.

Lam, K.S. 2006. Discovery of novel metabolites from marine actinomycetes. Curr. Opin. Microbiol., 9: 245-251.

Manna, S., Sinha, A., Sadhukan, R., Chakrabarty, S.L. 1995. Purification, characterization and antitumor activity of L-asparaginase isolated from Pseudomonas stutzeri MB-405. Curr. Microbiol., 30: 291-298.

Meena, B., Anburajan, L., Sathish, T., VijayaRaghavan, R., Dharani, G., Vinothumar, N.V., Kirubagaran, R. 2015. L asparaginase from Streoptomyces griseus NIOTVKMA29: optimisation of process variables using factorial designs and molecular characterization of $\mathrm{L}$ asparaginase genes. Scientific Reports, 5: 12404.

Narayana, K.J.P., Kumar, K.G., Vijayalakshmi, M. 2007. Lasparaginase production by Streptomyces albidoflavus. Ind. J. Microbiol., 48: 331-336.

Paul, R., Dwight, J.R., William, F. 1991. Distribution of Actinomycetes in Near-Shore Tropical Marine Sediments. Appl. Environ. Microbiol., 57(4): 1102-1108.

Poorani, E., Dhevag, P., Saseetharan, M.K. 2009. L-asparaginase production by newly isolated marine Streptomyces sp. Strain EPD 27: Molecular identification. Int. J. Integrative Biol., (3): 150-155.

Porterj, N., Wilhelmj, J., Tresnerh. D. 1960. Method for the preferential isolation of actinomycetes from the soil. Appl. Microbiol., 8: 174.

Resources Information Standards Committee. 1999. Voucher specimen collection, preparation, identification and storage protocol: Animals. Prepared for: Ministry of Environment, Lands and Parks, Resources Inventory Branch for the Terrestrial Ecosystems Task Force, Resources Inventory Committee, July 9.

Savithri, A.N., Azmi, W. 2003. Microbial Lasparaginase : A potent antitumour enzymes. Indian Jr. Biotechnol., 2: 184-194.

Selvakumar, D. 2011. Marine Streptomyces as a novel source of bioactive substances. World J. Microbiol. Biotechnol., 26: 2123-2139.

Selvam, K., Vishnupriya, B. 2013. Partial purification and cytotoxic activity of $\mathrm{L}$ asparaginase from stretomyces acrimycini NGP. Int. J. Res. Pharma. Biomed. Sci., 3: 859 - 869.

Shirling, E.B., Gottlieb, D. 1966. Methods For Characterization Of Streptomyces Species' Int. J. Systematic Bacteriol., 16(3): pp. 313-340.

Sivakumar, K., Sabu, M.K., Manivel, P.R. 2006. Optimum conditions for Lglutaminase production by actinomycete strain isolated from estuarine fish, Chanas chanas, Indian J. Experimental Biol., 44 : 256-258.

Takizawa, M., Colwell, R.R., Hill, R.T. 1993. Isolation and diversity of actinomycetes in the Chesapeake Bay. Appl. Environ. Microbiol., 59: 997-1002. 
Suvathi Sugasini, S., Aysha, O.S., Nirmala, P., Vinoth Kumar, P., Reena, A. 2012. Antimicrobial potential of Actinomycetes species isolated from marine environment. Asian Pac. J. Trop. Biomed., 2(6): 469-473.
Waksman, S.A. 1961. The Actinomycetes: Classification, identification and descriptions of genera and species. The Williams and Wilkins Company, Baltimore., 2: 61-292.

\section{How to cite this article:}

Dhevagi, P., and Poorani, E. 2016. L-Asparaginase from Marine Actinomycetes of Thoothukudi Coastal Ecosystem. Int.J.Curr.Microbiol.App.Sci. 5(7): 295-306.

doi: http://dx.doi.org/10.20546/ijcmas.2016.507.031 